\title{
DORMANCY STUDIES ON Euphorbia dracunculoides AND Astragalus spp.: MAJOR WEEDS OF ARID AREAS ${ }^{1}$
}

\author{
Estudos sobre Dormência de Euphorbia dracunculiodes e Astragalus spp.: Principais Ervas \\ Daninhas das Zonas Áridas
}

IKRAM, R.M. ${ }^{2}$, TANVEER, A. ${ }^{2}$, ATA, $Z_{.}^{2}$, and SAQIB, M. ${ }^{2}$

\begin{abstract}
The aim of this study was to examine the dormancy behavior of Euphorbia dracunculoides and Astragalus spp., weeds of arid chickpea. The dormancy breaking treatments were: Gibberalic acid $\left(\mathrm{GA}_{3}\right)$ and Thiourea each at 50,100, 150, 200, 250, and $300 \mathrm{ppm}$ and Potassium nitrate $\left(\mathrm{KNO}_{3}\right)$ at $5,000,10,000,15,000,20,000,25,000$, and 30,000 ppm (24 h soaking). Germination (G) percentage and germination energy (GE) of E. dracunculoides was maximum ( 89 and 22 , respectively) at $250 \mathrm{ppm}$ concentration of $\mathrm{GA}_{3}$ and 81.50 and 11.50 at $15000 \mathrm{ppm}$ concentration of $\mathrm{KNO}_{3}$. Thiourea at 250 and $300 \mathrm{ppm}$ resulted in maximum G percentage (51) and GE (25.50) of E. dracunculoides, whereas the G percentage and GE of Astragalus spp. were maximum (28 and 19, respectively) at the lowest concentration of $\mathrm{GA}_{3}$ $(50 \mathrm{ppm})$. On the other hand, $5000 \mathrm{ppm}$ and $150 \mathrm{ppm}$ concentration of $\mathrm{KNO}_{3}$ and Thiourea showed maximum GE (19.5) and G percentage (28) of Astragalus spp., respectively. Overall, effective dormancy breaking chemical against $E$. dracunculoides was $\mathrm{GA}_{3}(250 \mathrm{ppm})$ while in Astragalus spp. none of chemicals showed very impressive results. These results showed that both weeds' seeds have dormancy in their habit. Hot water treatment and the above mentioned chemicals (best concentrations) when used with 4, 8, and 12 hours soaking showed ineffective results.
\end{abstract}

Keywords: $\mathrm{GA}_{3}, \mathrm{KNO}_{3}$, thiourea, dormancy, E. dracunculoides, and Astragalus spp.

\begin{abstract}
RESUMO - O objetivo deste estudo foi analisar o comportamento de dormência de Euphorbia dracunculoides e Astragalus spp., ervas daninhas de grão de bico árido. Tratamentos de quebra da dormência foram: ácido Gibberalic $\left(G_{3}\right)$ e tioureia cada a 50, 100, 150, 200, 250 e 300 ppme de nitrato de potássio (KNO3) em 5.000, 10.000, 15.000, 20.000, 25,000 e 30,000 ppm (24 horas de imersão) . Germinação (G) e porcentagem de energia de germinação (GE) de E. dracunculoides foi máxima (89 e 22, respectivamente) a 250 ppm de concentração de $G A_{3}$ e 81,50 e 11,50 a 15000 ppm de concentração de $\mathrm{KNO}_{3}$. Thioureea a 250 e 300 ppm resultou em percentagem máxima de L (51) e GE $(25,50)$ de E. dracunculoides. Considerando G porcentagem e GE de Astragalus spp. foi máxima (28 e 19, respectivamente), a menor concentração de $G A_{3}(50$ ppm). Por outro lado, de 5000 ppm e 150 ppm de concentração de $\mathrm{KNO}_{3}$ e tioureia mostrou máximo GE $(19,5)$ e G percentagem (28) do Astragalus spp., respectivamente. Acima de tudo, quebrando a dormência química eficaz contra E. dracunculoides foi $\mathrm{GA}_{3}(250 \mathrm{ppm})$, enquanto em Astragalus spp., nenhum dos produtos quimicos mostraram resultados impressionantes. Estes resultados mostraram que ambas as ervas daninhas sementes apresentam dormência em seu hábito. Tratamento de água quente e produtos quimicos acima mencionados (melhores concentrações) quando usado com 4, 8 e 12 horas de imersão apresentaram resultados ineficazes.
\end{abstract}

Palavras-chave: $\mathrm{GA}_{3}, \mathrm{KNO}_{3}$, tioureia, dormência, E. dracunculoides e Astragalus spp.

Recebido para publicação em 29.5.2014 e aprovado em 22.7.2014.

University of Agriculture, Faisalabad, Pakistan, <drasiftanveeruaf@hotmail.com>.

Planta Daninha, Viçosa-MG, v. 32, n. 4, p. 747-753, 2014 


\section{INTRODUCTION}

Worldwide, of all the species of plants, only $3 \%$ are weeds and among them only 200-250 are said to be a major problem. Weeds are characterized by many factors i.e. abundant seed production, rapid population establishment, seed dormancy, long-term survival of buried seed, adaptation for spread, presence of vegetative reproductive structures and ability to occupy sites disturbed by humans (Lingenfelter \& Hartwig, 2013) that make them stronger to compete or invade.

Dormancy is a common feature of many weed seeds (Roberto et al., 2000) that describe the conditions in which the seed is able to germinate (Finch-Savage \& Leubner-Metzger, 2006). Germination of weed seeds has been under great influence of growth hormones like $\mathrm{GA}_{3}, \mathrm{KNO}_{3}$, Thiourea and sodium azide to break seed dormancy (Vieira et al., 2002; Cetinbas \& Koyuncu, 2006; Khan \& Shah, 2011). The effective $\left(\mathrm{GA}_{3}\right)$ and ineffective (Thiourea and $\mathrm{KNO}_{3}$ ) behavior at different concentrations on different plant seeds has been reported by Vieira et al. (2002) and Ali et al. (2011).

Dormancy is of different kinds and its understanding is of ecological importance. This information can be used for management programs and species reintroduction (Koyuncu, 2005; Ortega-Base \& Rojas-Arechiga, 2007). The dormancy behavior of weed seeds helps them to dodge weeding practices such as herbicides and makes them successful in persisting in the agro-ecosystem (Tang et al., 2008; Khan \& Shah, 2011). Efficient crop production can be achieved by assisting the new methods of dormancy release (Gu et al., 2004).

Euphorbia dracunculoides and Astragalus spp. are major annual and broad leave leaf weeds of rain fed chickpea-chickpea mono cropping system in Pakistan, and chickpea is grown from October to April on sandy soils in moisture conserved during summer rains. Euphorbia dracunculoides and Astragalus spp. germination, emergence and persistence have not been described for the arid environment. Worldwide, there is a lack of literature on comprehensive study of the seed dormancy problems of E. dracunculoides and Astragalus spp. Therefore, the objective of the present investigation was to determine the efficiency of gibberellic acid $\left(\mathrm{GA}_{3}\right)$, potassium nitrate $\left(\mathrm{KNO}_{3}\right)$ and Thiourea at different concentrations to overcome dormancy in E. dracunculoides and Astragalus spp.

\section{MATERIALS AND METHODS}

\section{Seed collection}

The mature seeds of E. dracunculoides and Astragalus spp. were collected using the random sampling technique in 2009 from southern arid areas of Pakistan. Immediately after collection, the seeds were isolated from the fruits and then separated from the undesired materials and unripe seeds on arrival at the laboratory. The seeds were stored in sealed paper bags after drying for a week in the shade under normal laboratory conditions $\left(25\right.$ to $\left.30^{\circ} \mathrm{C}\right)$. Only mature and uniform sized seeds were used in the experiments.

\section{Experiment 1: Effect of $\mathrm{GA}_{3}, \mathrm{KNO}_{3}$ and Thiourea on breaking the seed dormancy of Euphorbia dracunculoides and Astragalus spp.}

The seeds of both species were soaked in different concentrations of $\mathrm{GA}_{3}$ and Thiourea (50 ppm, 100 ppm, 150 ppm, 200 ppm, 250 ppm and $300 \mathrm{ppm})$ and $\mathrm{KNO}_{3}(5,000 \mathrm{ppm}$, $10,000 \mathrm{ppm}, 15,000 \mathrm{ppm}, 20,000 \mathrm{ppm}$, $25,000 \mathrm{ppm}$ and $30,000 \mathrm{ppm}$ ) for 24 hours at $18{ }^{\circ} \mathrm{C}$ for each species separately.

\section{Experiment 2: Effect of hot water treatment on breaking the seed dormancy of Euphorbia dracunculoides and Astragalus spp.}

The seeds of E. dracunculoides and Astragalus spp. were soaked for $15,30,45,60$, $75,90,105$ and 120 minutes in water when it started boiling and were removed after the prescribed period and allowed to cool at room temperature.

\section{Germination test}

After rinsing, the seeds were allowed to sun dry on the blotter paper at $19^{\circ} \mathrm{C}$ before 
placing them in Petri dishes in the above stated experiments. Petri dishes with a $9 \mathrm{~cm}$ diameter were washed with a $5 \%$ sodium hypochlorite $(\mathrm{NaOCl})$ solution for $5 \mathrm{~min}$ and subsequently rinsed five times with sterilized water. After drying, the petri dishes were subjected to sterilization in an ultraviolet machine for 2 minutes. Seeds were placed on double layered Watt man No. 10 filter paper moistened with $5 \mathrm{~mL}$ of distilled water in sterilized Petri dishes after each treatment. All dishes were sealed with a strip of paraffin to reduce water loss (Nadjafi et al., 2006) and placed at room maximum $\left(20^{\circ} \mathrm{C}\right)$ and minimum temperature $\left(17^{\circ} \mathrm{C}\right)$. A completely randomized design for each experiment with four replications was used and 25 seeds were assigned per replicate. Germination counts were made every day for 2 weeks. Seeds were considered to be germinated when the tip of the radical $(2 \mathrm{~mm})$ had grown free of the seed coat (Auld et al., 1988). Each experiment was carried out twice and statistical analysis was performed on the mean of the two replicates. The $G$ percentage was calculated by the following formula as described by Association of Official Seed Analysis (AOSA, 1990):

Germination percentage $=\frac{\text { Germinated seeds }}{\text { Total seeds }} \times 100$

Germination energy $=\frac{\text { Seeds count on } 4^{\text {th }} \text { day }}{\text { Total seeds }} \times 100$
The data collected were analyzed by using the Fisher's analysis of the variance function of MSTAT statistical computer package and LSD at $5 \%$ probability was used to compare the treatment's means (Steel et al., 1997).

\section{RESULTS AND DISCUSSION}

\section{Effect of $\mathrm{GA}_{3}$ on the germination percentage and germination energy of Euphorbia dracunculoides and Astragalus spp.}

Effect of the $\mathrm{GA}_{3}$ on $\mathrm{G}$ percentage and GE of $E$. dracunculoides showed significantly different results than not soaked (control) and seeds soaked in distilled water (Figures 1 and 2). All $\mathrm{GA}_{3}$ concentrations increased the $\mathrm{G}$ percentage and $\mathrm{GE}$ of E. dracunculoides gradually from low concentration to higher concentrations up to a $250 \mathrm{ppm}$ (89) and then decline (82) a little bit at the highest concentration (300 ppm) but were much more than the not soaked (control) and distilled water treated seeds. However, the opposite results were observed in Astragalus spp. The lowest concentration of $\mathrm{GA}_{3}(50 \mathrm{ppm})$ resulted in the maximum G percentage (28) and GE (19) of Astragalus spp. Both $\mathrm{G}$ percentage and $\mathrm{GE}$ decreased with increased $\mathrm{GA}_{3}$ concentration. The results of the distilled water treated seeds were statistically at par with those of $50 \mathrm{ppm}$ $\mathrm{GA}_{3}$ treated seeds.

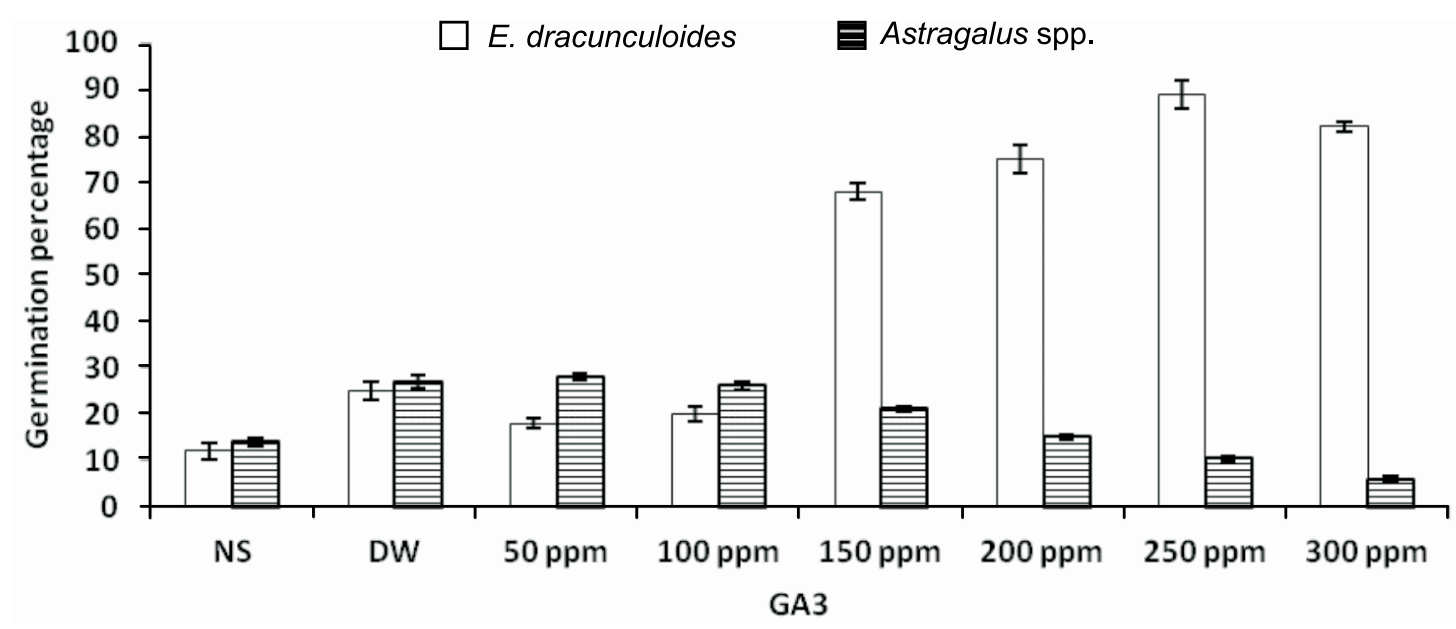

$\mathrm{NS}=$ not soaked, $\mathrm{DW}=$ distilled water

Figure 1 - Effect of $\mathrm{GA}_{3}$ on the seed germination percentage of E. dracunculoides and Astragalus spp. 


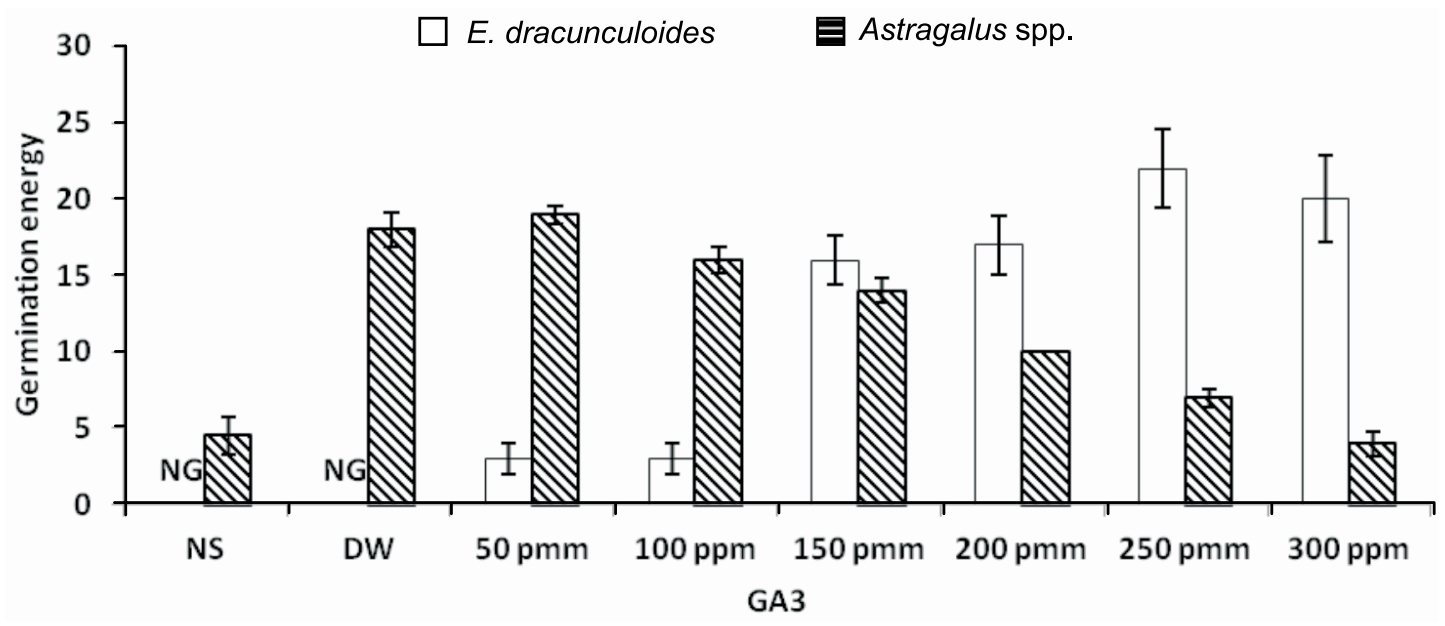

$\mathrm{NG}=$ not germinated, $\mathrm{NS}=$ not soaked, $\mathrm{DW}=$ distilled water.

Figure 2 - Effect of $\mathrm{GA}_{3}$ on the seed germination energy of E. dracunculoides and Astragalus spp.

Euphorbia dracunculoides germination results in our study are similar to those of Karam \& Al-Salem (2001) and Rahman et al. (2006) who reported that a $250 \mathrm{ppm}$ concentration of $\mathrm{GA}_{3}$ gave maximum $\mathrm{G}$ (31.67 and $86 \%$ ) in Allium sativum and Arbuts andrachne, respectively. In contrast, Koyuncu (2005) and Ghahfarokhi \& Afshari (2007) noted that $1,000 \mathrm{ppm} \mathrm{GA}$ application proved more effective against black mulberry than any of other $\mathrm{GA}_{3}$ concentration $(0,250$, $500,1,000$ and $2,000 \mathrm{ppm}$ ) but an increase in concentration resulted in an increase in G percentage. In Astragalus spp, contradictory results were reported by Keshtkar et al. (2008) whose study revealed that maximum G $(81 \%)$ of Astragalus cyclophyllon was achieved when the seeds were treated with a $500 \mathrm{ppm}$ concentration of $\mathrm{GA}_{3}$. But the results of Khan et al. (2002) showed no significant effect of $\mathrm{GA}_{3}$ concentrations $(50,300$ and $500 \mathrm{ppm}$ ) on final $\mathrm{G}$ percentage of grape fruit (C. paradisi) and kinnow mandarin (C. reticulate). Controversial results may be due to the species difference.

\section{Effect of $\mathrm{KNO}_{3}$ on germination percentage and germination energy of Euphorbia dracunculoides and Astragalus spp.}

The germination percentage and GE of E. dracunculoides was maximum $(81.50$ and 11.50 , respectively) at $15,000 \mathrm{ppm}$ concentration of $\mathrm{KNO}_{3}$ (Figure 3 ). All the other concentrations of $\mathrm{KNO}_{3}$ were statistically at par with one another in terms of $\mathrm{G}$ percentage while a $30,000 \mathrm{ppm}$ concentration was higher in GE than 10,000, 20,000, and 25,000 ppm concentrations of $\mathrm{KNO}_{3}$. All $\mathrm{KNO}_{3}$ concentrations showed a significantly higher $\mathrm{G}$ percentage and GE than the distilled water treated and non-soaked seeds, whereas distilled water treated seeds showed a higher $\mathrm{G}$ percentage than non-soaked seeds. Astragalus spp. behavior (Figure 4) toward $\mathrm{KNO}_{3}$ concentrations was not as responsive in breaking dormancy as distilled water but the lowest concentration $(5,000 \mathrm{ppm})$ was statistically at par with distilled water treated seeds and showed almost double G percentage than non-soaked seeds of Astragalus spp. G percentage and GE of Astragalus spp. declined with increase in concentrations of $\mathrm{KNO}_{3}$ up to $25,000 \mathrm{ppm}$ but a little bit higher at 30,000 ppm which was statistically similar with that of the 20,000 ppm $\mathrm{KNO}_{3}$ concentration.

Similar results were observed by Ramzan et al. (2010) who stated that among the $\mathrm{KNO}_{3}$ concentrations $(10,000,20,000,30,000,40,000$ and $50,000 \mathrm{ppm})$ lower concentrations (10000 and 20,000 $\mathrm{ppm}$ ) and distilled water were more effective than that of higher concentrations when tested against Allium sativum seeds. Nitrogen containing compounds like $\mathrm{KNO}_{3}, \mathrm{NaNO}_{3}, \mathrm{NHNO}_{3}$ and $\mathrm{NH}_{4} \mathrm{Cl}$ enhanced the seed germination of Centaurea tomentella, Chenopodium album and other plants (Uysal 


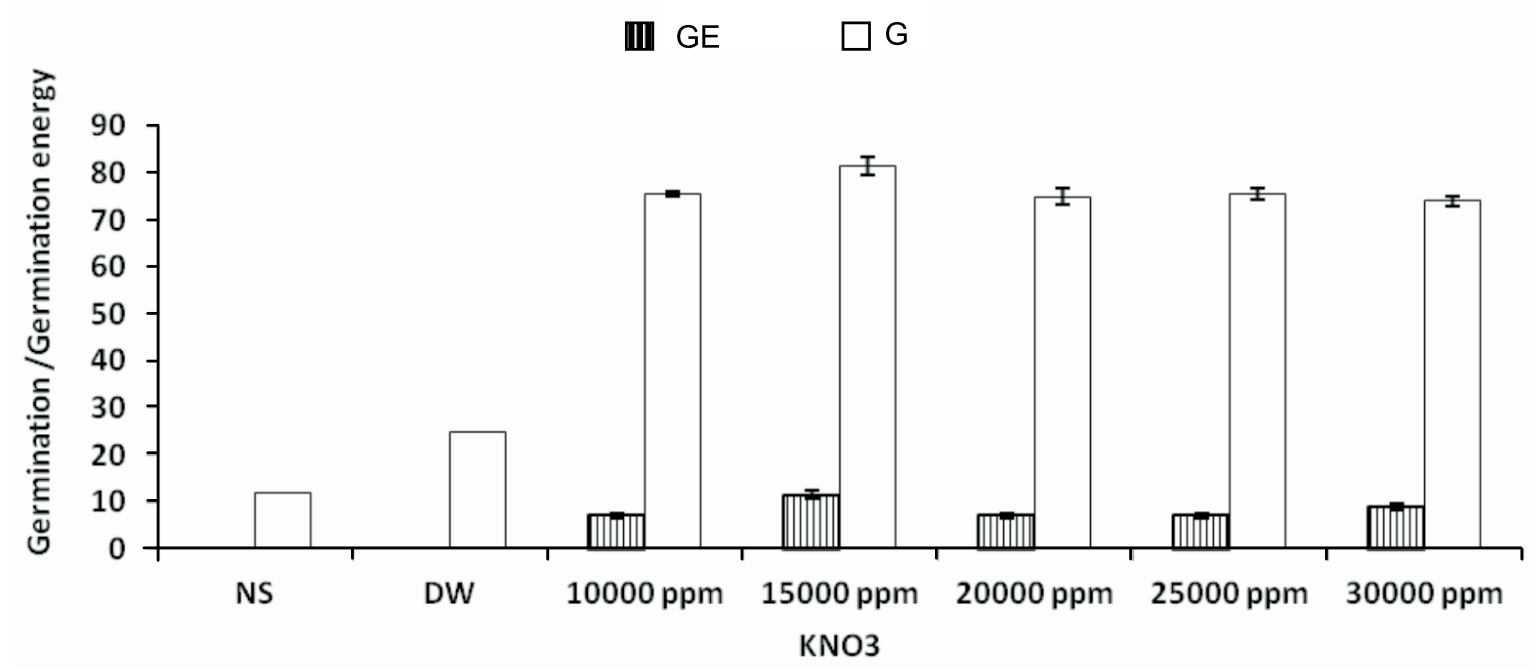

$\mathrm{NS}=$ not soaked, $\mathrm{DW}=$ distilled water.

Figure 3 - Effect of $\mathrm{KNO}_{3}$ on the seed germination percentage and germination energy of E. dracunculoides.

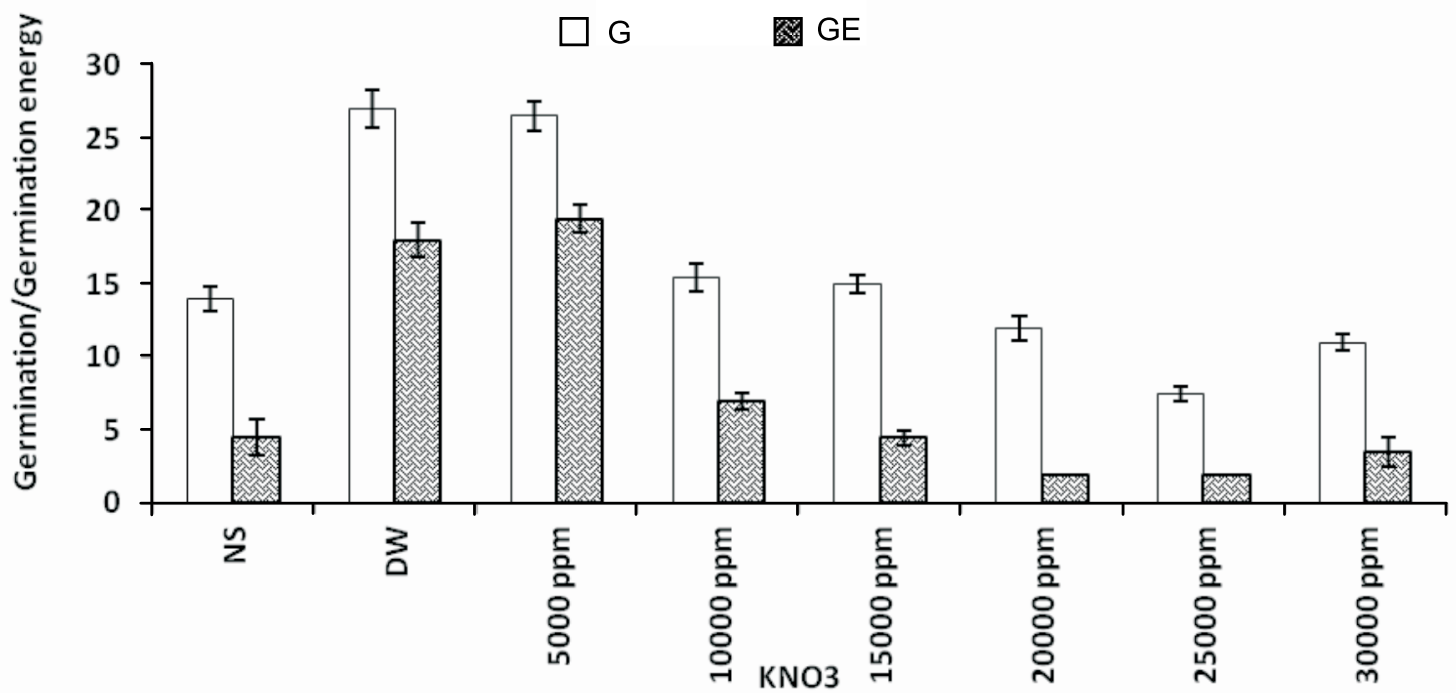

$\mathrm{NS}=$ not soaked, $\mathrm{DW}=$ distilled water.

Figure 4 - Effect of $\mathrm{KNO}_{3}$ on the seed germination percentage and germination energy of Astragalus spp.

et al., 2006; Tang et al., 2008; Khan \& Shah, 2011).

Effect of Thiourea on the germination percentage and germination energy of Euphorbia dracunculoides and Astragalus spp.

An increase in the Thiourea concentration statistically increased the $G$ percentage of E. dracunculoides compared to distilled water treated and non-soaked (control) seeds and maximum (51\%) G was observed at $250 \mathrm{ppm}$, whereas GE was maximum (25.50) at $300 \mathrm{ppm}$ Thiourea, which was statistically at par with 100, 150 and $250 \mathrm{ppm}$ (Figures 5 and 6). Astragalus spp., showed maximum G percentage and GE $(28,18$, respectively) at $150 \mathrm{ppm}$ Thiourea which were statistically similar to those of distilled water $(27,17$, respectively). Thiourea concentrations up to 200 ppm increased the seed G percentage of 


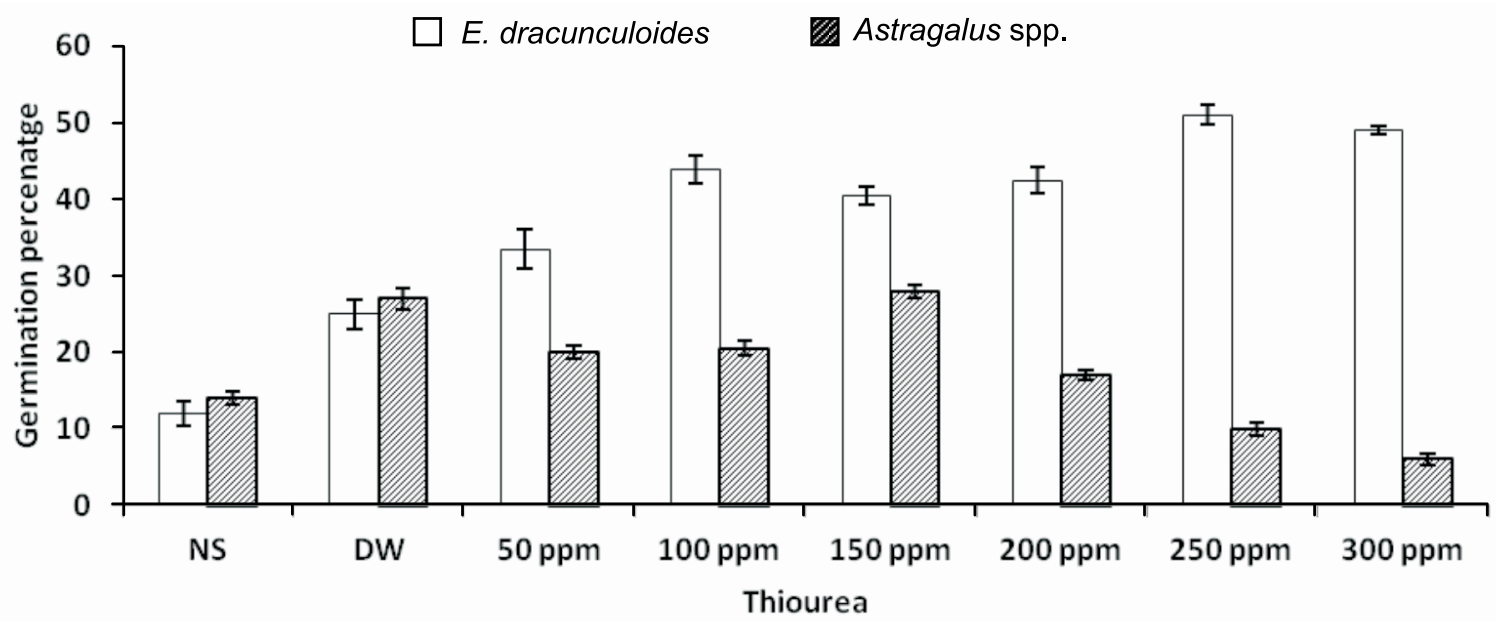

$\mathrm{NS}=$ not soaked, $\mathrm{DW}=$ distilled water

Figure 5 - Effect of Thiourea on the seed germination percentage of E. dracunculoides and Astragalus spp.

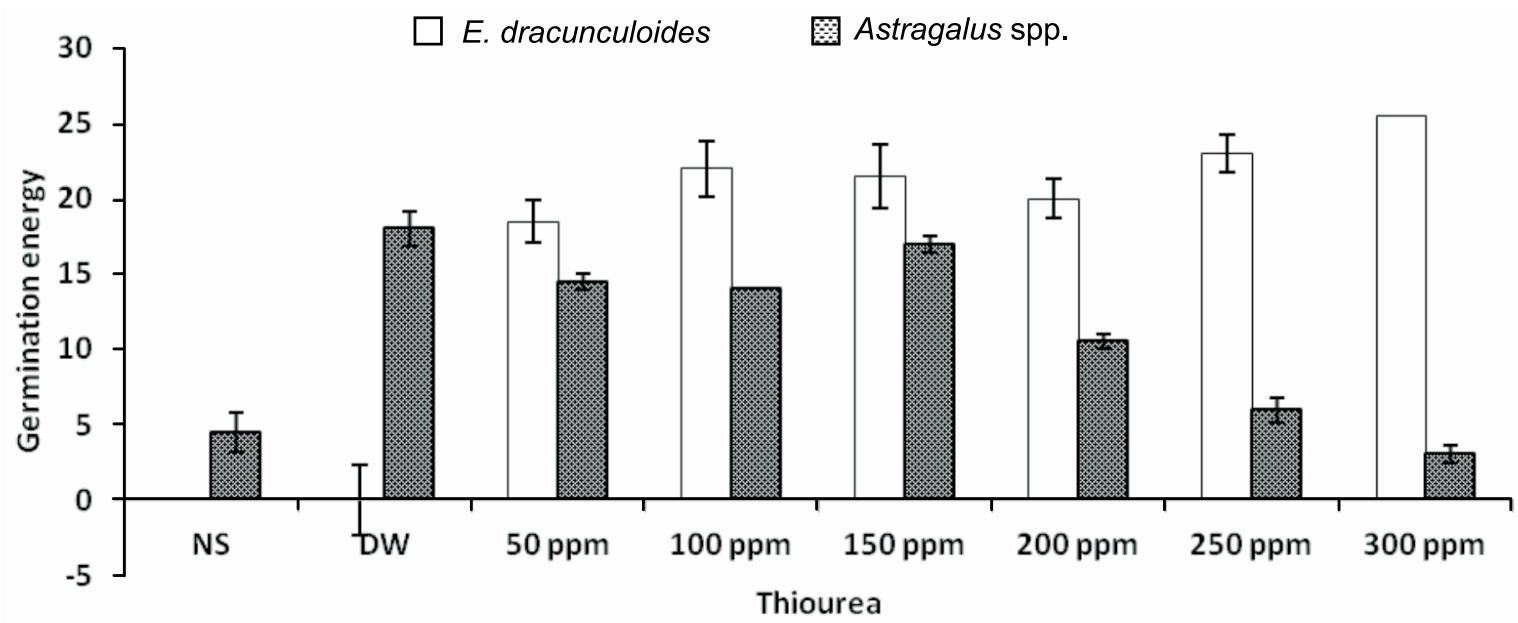

$\mathrm{NS}=$ not soaked, DW $=$ distilled water.

Figure 6 - Effect of Thiourea on the germination energy of E. dracunculoides and Astragalus spp.

Astragalus spp. compared to non-soaked seeds. Astragalus spp. showed significantly less G percentage at the highest concentrations of Thiourea (250 and $300 \mathrm{ppm}$ ) than the nonsoaked seeds. Astragalus spp. showed higher G energy at all the concentrations of Thiourea except 300 ppm compared to non-soaked seeds.

Khan et al. (2003) reported that G of A. prostrata was stimulated by Thiourea and nitrate compounds. In another study, Erez (2005) stated that Thiourea promoted growth in soybean, tobacco, and apple. Ali et al. (2011) revealed contradictory results, as Thiourea and $\mathrm{KNO}_{3}$ were ineffective in breaking seed dormancy of Rhynochosia capitata.

In conclusion, these results suggest that $\mathrm{GA}_{3}$ and $\mathrm{KNO}_{3}$ were the most and Thiourea was the less effective in breaking the seed dormancy of E. dracunculoides, while in Astragalus spp. all three chemicals were not very effective but gave a little bit higher germination compared to control (non-soaked). 


\section{ACKNOWLEDGMENTS}

This manuscript is a part of thesis research work of the principal author for a Ph.D. degree in the Department of Agronomy, University of Agriculture, Faisalabad, Pakistan. The authors of this manuscript greatly acknowledge the Higher Education Commission, Islamabad, Pakistan for the financial support to conduct the present study.

\section{LITERATURE CITED}

ALI, H. H. et al. Methods to break seed dormancy of Rhynchosia capitata, a summer annual weed, Chil. J. Agric. Res., v. 71, n. 3, p. 483-487, 2011.

ASSOCIATION OF OFFICIAL SEED ANALYSIS - AOSA. Rules for testing seeds. J. Seed Technol., v. 12, n. 3, p. 1112, 1990.

AULD, D. L. et al. Planting data and temperature effects on germination, and seed yield of chickpea. Agron. J., v. 80, n. 6, p. 909-914, 1988.

CETINBAS, M.; KOYUNCU, F. Improving germination of Prunus avium L. seeds by gibberellic acid, potassium nitrate and Thiourea. Hortic. Sci., v. 33, n. 3, p. 119-23, 2006.

EREZ, A. Thiourea, a Growth Promoter of Callus Tissues. J. Exper. Bot., v. 29, n. 1, p. 159-165, 2005.

FINCH-SAVAGE, W. E.; LEUBNER-METZGER, G. Seed dormancy and the control of germination. New Phytol., v. 171, n. 3, p. 501-523, 2006.

GHAHFAROKHI, A. R.; AFSHARI, R. T. Methods of dormancy breaking and germination of Galbanum seeds (Ferrula Gummosa). Asian J. Plant. Sci., v. 6, n. 4, p. 611-616, 2007.

GU, X-Y. et al. Multiple loci and epistases control genetic variation for seed dormancy in weedy rice (Oryza sativa). Genetics, v. 166, n. 3, p. 1503-1516, 2004.

KARAM, N. S.; AL-SALEM M. M. Breaking dormancy in Arbutus andrachna L. seeds by stratification and gibberellic acid. Seed Sci. Technol., v. 29, n. 1, p. 51-56, 2001.

KESHTKAR, A. R. et al. Methods to break seed dormancy of Astragalus cyclophyllon. African J. Biotechnol., v. 7, n. 21, p. 3874-3877, 2008.

KHAN, M. A. et al. Alleviation of salinity-enforced seed dormancy in Atriplex prostrata. Pak. J. Bot., v. 35, n. 5, p. 906-912, 2003.
KHAN, M. I.; SHAH, F. Effect of potassium nitrate and Thiourea on seed germination of crops and weeds. African Crop Sci. Conf. Proc., v. 10, p. 461-463, 2011.

KHAN, M. M. et al. Role of gibberellic acid $\left(\mathrm{KNO}_{3}\right)$ on citrus seed germination and study of some morphological characteristics. Pak. J. Agri. Sci., v. 39, n. 2, p. 113-118, 2002.

KOYUNCU, F. Breaking seed dormancy in black mulberry (Morus nigra L.) by cold stratification and exogenous application of gibberellic acid. Acta Biol. Cracoviensia Ser. Bot., v. 47, n. 2, p. 23-26, 2005.

LINGENFELTER, D. D.; HARTWIG, N. L. Introduction to weeds and herbicides. Produced by $\mathrm{Ag}$ Communications and Marketing, The Pennsylvania State University, 2013. 4 p.

NADJAFI, F. et al. Seed germination and dormancy breaking techniques for Ferula gummosa and Teucrium polium.

J. Arid Enviriron., v. 64, n. 3, p. 542-547, 2006.

ORTEGA-BAES P.; ROJAS-ARECHIGA, M. Seed germination of Trichocereus terscheckii (Cactaceae): Light, temperature and gibberellic acid effects. J. Arid Environ., v. 69, n. 1, p. 169-176, 2007.

RAHMAN, M. H. et al. Effects of Gibberellic Acid $\left(\mathrm{KNO}_{3}\right)$ on breaking dormancy in Garlic (Allium sativum L.). Intern. J. Agric. Biol., v. 8, n. 1, p. 63-65, 2006.

RAMZAN, A. et al. Effect of priming with potassium nitrate and dehusking on seed germination of gladiolus (Gladiolus Alatus). Pak. J. Bot., v. 42, n. 1, p. 247-258, 2010.

ROBERTO, L. B. et al. Environmental control of dormancy in weed seed banks in soil. Field Crops Res., v. 67, n. 2, p. 105-122, 2000.

STEEL, R. G. D. et al. Principles and procedures of statistics. A biometrical approach 3.ed. Singapore, McGraw Hill Book Co., 1997. p. 172-177.

TANG, D. S. et al. Role of Red Light, Temperature, Stratification and Nitrogen in Breaking Seed Dormancy of Chenopodium album L. J. Crop Sci. Biotechnol., v. 11, n. 3, p. 199-204, 2008.

UYSAL, I. et al. Studies on the germination of an endemic species Centaurea tomentella hand. -mazz., Pak. J. Bot., v. 38, n. 4, p. 983-989, 2006.

VIEIRA, A. R. et al. Action of gibberellic acid $\left(\mathrm{GA}_{3}\right)$ on dormancy and activity of á-amylase in rice seeds. R. Bras. Sementes, v. 24, n. 2, p. 43-48, 2002. 